\title{
A variant form of Takotsubo syndrome secondary to Sumatriptan: A case report
}

\author{
Sulaiman Rathore, Dexter deLeon \\ Department of Cardiology, Virginia-Tech Carilion School of Medicine and Research Institute, Roanoke, VA, USA.
}

Correspondence: Sulaiman Rathore. Address: 127 McClanahan St. Suite 300, Roanoke, VA 24014, USA. Email: srathore@carilionclinic.org

Received: March 10, 2014

Accepted: May 4, 2014

Online Published: May 13, 2014

DOI : $10.5430 /$ crim.v1n2p120

URL: http://dx.doi.org/10.5430/crim.v1n2p120

\section{Abstract}

Takotsubo syndrome (TS), also known as stress-induced cardiomyopathy or broken heart syndrome, is an acute reversible left ventricular systolic dysfunction that mimics an acute coronary syndrome. It has various types and mechanism of pathogenesis is not very well defined. It is more common in postmenopausal women and is associated with emotional or physical stress. We report a case of type III takotsubo syndrome in a postmenopausal woman after taking sumatriptan for migraine headache.

\section{Keywords}

Takotsubo syndrome, Stress-induced cardiomyopathy, Sumatriptan, Triptan, Migraine headache

\section{I ntroduction}

Takotsubo syndrome (TS) is an acute reversible left ventricular (LV) systolic dysfunction. It usually mimics an acute coronary syndrome presenting with chest pain or dyspnea, electrocardiographic abnormalities and elevated cardiac biomarkers ${ }^{[1]}$. It is characterized by an abnormal LV segmental contractility without any evidence of obstructive coronary artery disease ${ }^{[2]}$. Takotsubo syndrome is also known as stress induced cardiomyopathy, apical ballooning syndrome or "Broken heart syndrome".

It is more common in women, particularly post-menopausal and a trigger in the form of physical or psychological stress can be detected in a classical presentation ${ }^{[1]}$. Several triggers have been described in literature inducing TS. We describe a rare case of variant form of TS in a woman after taking sumatriptan for her migraine headache.

\section{Case report}

A 51 year-old caucasian female was transferred to our facility for management of non-ST elevation myocardial infarction. She presented to the referring emergency department with sudden onset of substernal chest pain. Her past medical history was significant for chronic obstructive pulmonary disease, hypothyroidism, tobacco use, migraine headaches, depression and a remote history of deep venous thrombosis. She was taking topiramate, levothyroxine, temezapam, aspirin, bupropion and as needed sumatriptan. Her last use of sumatriptan was two years ago. She reported use of sumatriptan as an 
abortive therapy for her severe migraine headache. Thirty minutes after taking sumatriptan she developed sudden substernal chest pain and presented to the emergency department. Her initial workup showed stable hemodynamics and Twave inversions in anterolateral leads on electrocardiogram. Initial cardiac enzymes, Troponin I, were normal but subsequent Troponin I became elevated to 0.44 (normal $<0.30 \mathrm{ng} / \mathrm{mL}$ ) and she was transferred to our facility for further management. She was given an oral aspirin $325 \mathrm{mg}$, clopidogrel $300 \mathrm{mg}$ and one dose of subcutaneous injection of enoxaparin $1 \mathrm{mg} / \mathrm{kg}$ body weight by the sending facility. She was also treated with intravenous morphine and topical nitroglycerin paste for her chest pain. On presentation to our hospital she was chest pain free, headache had subsided, hemodynamically stable and her cardiac exam was within normal limits. Her repeat electrocardiogram showed persistent T wave inversions in leads V1-3 and avL. In addition to dual antiplatelet therapy she was also started on beta-blockers, atorvastatin and an echocardiogram was performed. Her echocardiogram showed hypokinesia of mid to apical LV walls and an ejection fraction of $20 \%-25 \%$. Next morning, she was taken to cardiac catheterization laboratory for evaluation of her coronary arteries and severe LV systolic dysfunction. Her coronary angiograms showed normal coronary arteries (see Figure 1 and 2). The left ventriculogram showed severely hypokinetic mid-ventricular walls, normal contracting base and hyper-contractile apex consistent with type III takotsubo cardiomyopathy (see Figure 3).

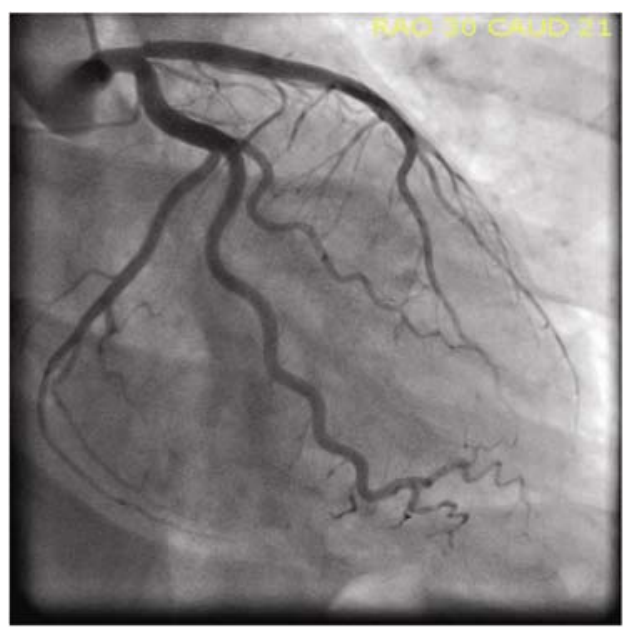

Figure 1. Coronary angiogram showing normal left coronary artery circulation.

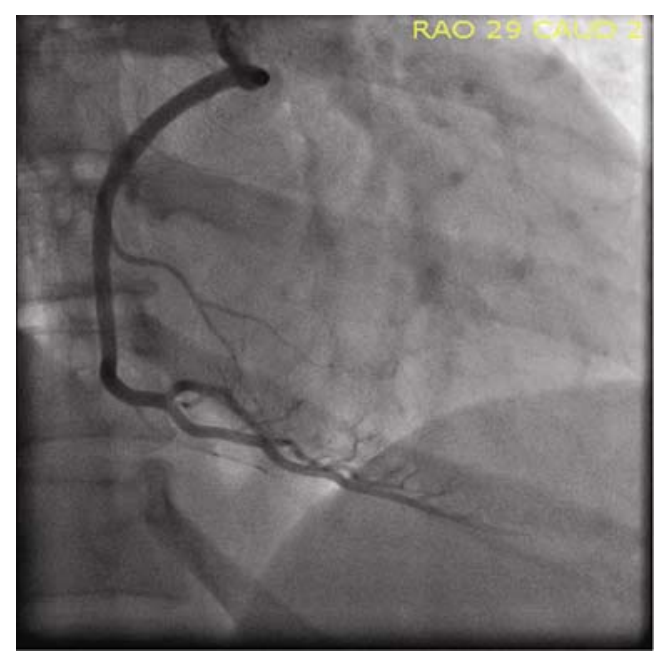

Figure 2. Coronary angiogram showing normal right coronary circulation. 


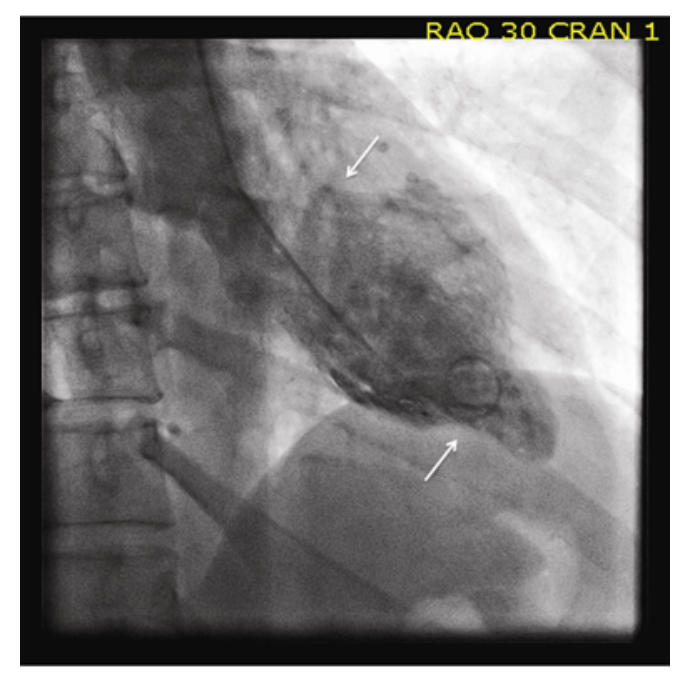

Figure 3. Left ventriculogram showing mid-ventricular ballooning and basal and apical hypercontractility consistent with type III takotsubo morphology (arrows).

The patient had no post procedural complications. Next day, she was discharged from the hospital on aspirin, carvedilol, lisinopril and her sumtriptan was stopped. She followed up at our office after 8 weeks and a repeat echocardiogram showed improvement of LV systolic contractility and an ejection fraction of $45 \%-50 \%$ without any wall motion abnormalities. It was concluded that sumatriptan induced her chest pain and initial symptoms leading to TS.

\section{Discussion}

Japanese authors first described Takotsubo syndrome in 1990s ${ }^{[3]}$. The true prevalence of TS is unclear and there are no clear risk factors associated with TS ${ }^{[2]}$. The diagnostic criteria remain controversial and multiple criteria have been presented in literature ${ }^{[4-8]}$. Bybee el al published the Mayo clinic criteria in 2004, which have been modified recently by Prasad et al, and is the most commonly used criteria to diagnose TS ${ }^{[5,7]}$ (see Table 1).

Table 1. Diagnostic criteria of Takotsubo Syndrome

\begin{tabular}{ll}
\hline Mayo Clinic criteria & Prasad criteria \\
\hline $\begin{array}{l}\text { Suspicion of AMI based on precordial pain and ST } \\
\text { elevation observed on the acute-phase ECG }\end{array}$ & $\begin{array}{l}\text { Transient hypokinesia, akinesia, or dyskinesia of the middle } \\
\text { segments of the LV, with or without alterations at the apex. Regional } \\
\text { abnormalities of wall motility extend in the area of distribution of a } \\
\text { single epicardial vessel. }\end{array}$ \\
$\begin{array}{l}\text { Transient hypokinesia or akinesia of the middle and } \\
\text { apical regions of the LV and functional hyperkinesia of } \\
\text { the basal region, observed on ventriculography or } \\
\text { echocardiography }\end{array}$ & $\begin{array}{l}\text { Absence of an obstructed coronary artery or angiographic evidence } \\
\text { of acute rupture of a plaque }\end{array}$ \\
$\begin{array}{l}\text { Normal coronary arteries confirmed by arteriography } \\
\text { (luminal narrowing of less than 50\% in all the coronary } \\
\text { arteries) in the first } 24 \text { hours after the onset of symptoms } \\
\begin{array}{l}\text { New ECG abnormalities (ST elevation and/or T-wave inversion) or } \\
\text { elevation of cardiac troponin. }\end{array} \\
\begin{array}{l}\text { Absence of: } \\
\text { Remorrhage, suspicion of phead injury } \\
\text { myocarditis, or hypertrophic cardiomyopathy } \\
\text { Intracranial hemorrhage } \\
\text { Pheochromocytoma } \\
\text { Myocarditis }\end{array} \\
\text { Hypertrophic cardiomyopathy }\end{array}$
\end{tabular}


The LV adopts a shape of a pot, thus receiving its name takotsubo syndrome (in Japanese takotsubo means an octopus trap). Typically, LV appears with a narrow base and globular apex but atypical forms and variants of takotsubo syndrome have been described and can comprise up to one third of the total presentations ${ }^{[2,9]}$ (see Table 2).

Table 2. Types of Takotsubo Syndrome

Type I. Takotsubo cardiomyopathy with apical ballooning.

Type II. Midventricular ballooning.

Type III. Cardiomyopathy with apical hypercontractility.

Type IV. Basal ballooning.

Type V. Involvement of other segments.

The exact mechanism and pathogenesis of this disorder is unknown. The histological inflammatory changes in TS differ from coagulation necrosis as seen in myocardial infraction from coronary artery occlusion ${ }^{[1]}$. Multiple pathological mechanisms responsible for TS have been proposed. A few concepts are discussed below.

Multivessel epicardial coronary artery spasm resulting in reversible regional myocardial stunning ${ }^{[10]}$ has been proposed but this hypothesis does not explain the histological changes observed in TS ${ }^{[11]}$. Another hypothesis is coronary microvascular dysfunction ${ }^{[12]}$. Impaired microvascular function and myocardial metabolic disturbances have been found in patients with TS on basis of thallium-201 and 18 F-fluorodeoxyglucose myocardial scans ${ }^{[13]}$.

Increased catecholamine release from stress giving cardiotoxicity is another possibility ${ }^{[14,15]}$. Catecholamine produce vasoconstriction and direct myocyte damage from increase calcium release, which activates cAMP, causing myocyte damage and free radical release ${ }^{[10,16]}$. The myocardial histological changes in TS are similar to those seen in catecholamine cardiotoxicity in animals and humans ${ }^{[17,18]}$. Sympathetic nervous mechanisms causing release of catecholamine and giving myocardial stunning may also play a part in catecholamine-induced cardiotoxicity ${ }^{[1,19]}$. Low estrogen states increase the risk of microvascular dysfunction in high catecholamine conditions placing perimenopausal and postmenopausal women on higher risk to develop TS ${ }^{[2,20]}$.

Sumatriptan has a similar mechanism of action and adverse-effect profile as other triptans (e.g. zolmitriptan, fravotriptan) ${ }^{[21]}$. It is a 5HT1B/1D receptor agonist that has been approved for treatment of acute migraine headache. Cases of transient ischemia, myocardial infarction and arrhythmias have been described with use of 5HT1 receptor agonist ${ }^{[22-24]}$. 5HT1B receptor is known to cause coronary artery spasm and its expression has been demonstrated on coronary artery smooth muscle cell ${ }^{[25,26]}$. Theoretically, because sumatriptan can induce coronary vasospasm, it is quite possible that this vasospasm in setting of neurogenic insult like acute migraine headache can cause LV dysfunction leading to TS.

To our knowledge triptan induced TS has been reported once in literature ${ }^{[27]}$. Our case is unique because of variant form of TS with sumatriptan use for acute migraine headache in a postmenopausal woman. Migraine headache has been described as a risk factor for TS in a case report ${ }^{[28]}$, however our patient had similar episode in the past without complications. Therefore, we believe that migraine headache and use of sumatriptan in postmenopausal state caused her LV dysfunction leading to TS.

\section{Conclusion}

Takotsubo syndrome or cardiomyopathy is a novel form of heart failure that mimics acute coronary syndrome. Precipitating and pathological mechanisms are complex and not very well understood. Our case highlights medications acting on sympathetic system along with physical stress as a risk factor in developing TS in postmenopausal women. 


\section{References}

[1] Akashi YJ, Goldstein DS, Barbaro G, Ueyama T. Takotsubo cardiomyopathy: a new form of acute, reversible heart failure. Circulation. 2008; 118(25): 2754-62. PMID: 19106400. http://dx.doi.org/10.1161/CIRCULATIONAHA.108.767012

[2] Castillo Rivera AM, Ruiz-Bailen M, Rucabado Aguilar L. Takotsubo cardiomyopathy--a clinical review. Medical science monitor : international medical journal of experimental and clinical research. 2011; 17(6): RA135-47. PMID: 21629203. http://dx.doi.org/10.12659/MSM.881800

[3] Dote K, Sato H, Tateishi H, Uchida T, Ishihara M. [Myocardial stunning due to simultaneous multivessel coronary spasms: a review of 5 cases]. J Cardiol. 1991; 21(2): 203-14. PMID: 1841907.

[4] Abe Y, Kondo M. Apical ballooning of the left ventricle: a distinct entity? Heart. 2003; 89(9): 974-6. PMID: 12922993. http://dx.doi.org/10.1136/heart.89.9.974

[5] Bybee KA, Kara T, Prasad A, Lerman A, Barsness GW, Wright RS, et al. Systematic review: transient left ventricular apical ballooning: a syndrome that mimics ST-segment elevation myocardial infarction. Ann Intern Med. 2004; 141(11): 858-65. PMID: 15583228. http://dx.doi.org/10.7326/0003-4819-141-11-200412070-00010

[6] Kawai S, Kitabatake A, Tomoike H, Takotsubo Cardiomyopathy G. Guidelines for diagnosis of takotsubo (ampulla) cardiomyopathy. Circ J. 2007; 71(6): 990-2. PMID: 17527002. http://dx.doi.org/10.1253/circj.71.990

[7] Prasad A. Apical ballooning syndrome: an important differential diagnosis of acute myocardial infarction. Circulation. 2007; 115(5): e56-9. PMID: 17283269. http://dx.doi.org/10.1161/CIRCULATIONAHA.106.669341

[8] Segovia Cubero J, Peraira Moral R. [Transient apical ballooning syndrome: a transition towards adulthood]. Revista espanola de cardiologia. 2004; 57(3): 194-7. PMID: 15056421. http://dx.doi.org/10.1016/S0300-8932(04)77089-X

[9] Haghi D, Suselbeck T, Borggrefe M. Guidelines for diagnosis of takotsubo (ampulla) cardiomyopathy. Circ J. 2007; 71(10): 1664, author reply 5. PMID: 17895572.

[10] Kurisu S, Sato H, Kawagoe T, Ishihara M, Shimatani Y, Nishioka K, et al. Tako-tsubo-like left ventricular dysfunction with ST-segment elevation: a novel cardiac syndrome mimicking acute myocardial infarction. Am Heart J. 2002; 143(3): $448-55$. PMID: 11868050. http://dx.doi.org/10.1067/mhj.2002.120403

[11] Nef HM, Mollmann H, Weber M, Deetjen A, Brandt R, Hamm CW, et al. Release pattern of cardiac biomarkers in left ventricular apical ballooning. International journal of cardiology. 2007; 115(1): 128-9. PMID: 16769138. http://dx.doi.org/10.1016/j.ijcard.2006.01.034

[12] Kume T, Akasaka T, Kawamoto T, Yoshitani H, Watanabe N, Neishi Y, et al. Assessment of coronary microcirculation in patients with takotsubo-like left ventricular dysfunction. Circ J. 2005; 69(8): 934-9. PMID: 16041162. http://dx.doi.org/10.1253/circj.69.934

[13] Yoshida T, Hibino T, Kako N, Murai S, Oguri M, Kato K, et al. A pathophysiologic study of tako-tsubo cardiomyopathy with F-18 fluorodeoxyglucose positron emission tomography. Eur Heart J. 2007; 28(21): 2598-604. PMID: 17921529. http://dx.doi.org/10.1093/eurheartj/ehm401

[14] Stein AB, Tang XL, Guo Y, Xuan YT, Dawn B, Bolli R. Delayed adaptation of the heart to stress: late preconditioning. Stroke. 2004; 35(11 Suppl 1): 2676-9. PMID: 15459441. http://dx.doi.org/10.1161/01.STR.0000143220.21382.fd

[15] Ueyama T, Kasamatsu K, Hano T, Yamamoto K, Tsuruo Y, Nishio I. Emotional stress induces transient left ventricular hypocontraction in the rat via activation of cardiac adrenoceptors: a possible animal model of 'tako-tsubo' cardiomyopathy. Circ J. 2002; 66(7): 712-3. PMID: 12135146. http://dx.doi.org/10.1253/circj.66.712

[16] Nef HM, Mollmann H, Akashi YJ, Hamm CW. Mechanisms of stress (Takotsubo) cardiomyopathy. Nature reviews Cardiology. 2010; 7(4): 187-93. PMID: 20195267. http://dx.doi.org/10.1038/nrcardio.2010.16

[17] Frustaci A, Loperfido F, Gentiloni N, Caldarulo M, Morgante E, Russo MA. Catecholamine-induced cardiomyopathy in multiple endocrine neoplasia. A histologic, ultrastructural, and biochemical study. Chest. 1991; 99(2): 382-5. PMID: 1671211. http://dx.doi.org/10.1378/chest.99.2.382

[18] Movahed A, Reeves WC, Mehta PM, Gilliland MG, Mozingo SL, Jolly SR. Norepinephrine-induced left ventricular dysfunction in anesthetized and conscious, sedated dogs. International journal of cardiology. 1994; 45(1): 23-33. PMID: 7995660. http://dx.doi.org/10.1016/0167-5273(94)90051-5

[19] White M, Wiechmann RJ, Roden RL, Hagan MB, Wollmering MM, Port JD, et al. Cardiac beta-adrenergic neuroeffector systems in acute myocardial dysfunction related to brain injury. Evidence for catecholamine-mediated myocardial damage. Circulation. 1995; 92(8): 2183-9. PMID: 7554200. http://dx.doi.org/10.1161/01.CIR.92.8.2183

[20] Kaski JC. Cardiac syndrome X in women: the role of oestrogen deficiency. Heart. 2006; 92 Suppl 3: iii5-9. PMID: 16614266; http://dx.doi.org/10.1136/hrt.2005.070318 
[21] Evans RW, Martin V. Expert opinion: assessing cardiac risk prior to use of triptans. Headache. 2000; 40(7): 599-602. PMID: 10940101. http://dx.doi.org/10.1046/j.1526-4610.2000.00094.x

[22] MacIntyre PD, Bhargava B, Hogg KJ, Gemmill JD, Hillis WS. Effect of subcutaneous sumatriptan, a selective 5HT1 agonist, on the systemic, pulmonary, and coronary circulation. Circulation. 1993; 87(2): 401-5. PMID: 8381056. http://dx.doi.org/10.1161/01.CIR.87.2.401

[23] Mueller L, Gallagher RM, Ciervo CA. Vasospasm-induced myocardial infarction with sumatriptan. Headache. 1996; 36(5): 329-31. PMID: 8682677. http://dx.doi.org/10.1046/j.1526-4610.1996.3605329.x

[24] Stillman MJ, Tepper S, Tepper DE, Cho L. QT prolongation, Torsade de Pointes. Myocardial ischemia from coronary vasospasm, and headache medications. Part 1: review of serotonergic cardiac adverse events with a triptan case. Headache. 2013; 53(1): 208-16. PMID: 23216317. http://dx.doi.org/10.1111/j.1526-4610.2012.02300.x

[25] Ishida T, Hirata K, Sakoda T, Kawashima S, Akita H, Yokoyama M. Identification of mRNA for 5-HT1 and 5-HT2 receptor subtypes in human coronary arteries. Cardiovascular research. 1999; 41(1): 267-74. PMID: 10325974. http://dx.doi.org/10.1016/S0008-6363(98)00162-X

[26] Kaumann AJ, Frenken M, Posival H, Brown AM. Variable participation of 5-HT1-like receptors and 5-HT2 receptors in serotonin-induced contraction of human isolated coronary arteries. 5-HT1-like receptors resemble cloned 5-HT1D beta receptors. Circulation. 1994; 90(3): 1141-53. PMID: 8087924. http://dx.doi.org/10.1161/01.CIR.90.3.1141

[27] Garg J, Aronow WS, Devabhaktuni S, Ahmad H. Takotsubo Syndrome (or Apical Ballooning Syndrome) Secondary to Zolmitriptan. American journal of therapeutics. 2013. PMID: 24100257. http://dx.doi.org/10.1097/01.mjt.0000433938.07244.05

[28] Jalan P, Dhakal L, Pandav V, Omar AI. Status migrainosus as a potential stressor leading to takotsubo cardiomyopathy. Cephalalgia : an international journal of headache. 2012; 32(15): 1140-3. PMID: 22990688.

http://dx.doi.org/10.1177/0333102412459574 